IZA DP No. 7776

The Cyclical Behaviour of Employers' Monopsony Power and Workers' Wages

Boris Hirsch

Elke Jahn

Claus Schnabel

November 2013 


\title{
The Cyclical Behaviour of Employers' Monopsony Power and Workers' Wages
}

\author{
Boris Hirsch \\ University of Erlangen-Nuremberg \\ Elke Jahn \\ IAB Nuremberg, \\ Aarhus University and IZA \\ Claus Schnabel \\ University of Erlangen-Nuremberg \\ and IZA
}

\section{Discussion Paper No. 7776 \\ November 2013}

\author{
IZA \\ P.O. Box 7240 \\ 53072 Bonn \\ Germany \\ Phone: +49-228-3894-0 \\ Fax: +49-228-3894-180 \\ E-mail: iza@iza.org
}

\begin{abstract}
Any opinions expressed here are those of the author(s) and not those of IZA. Research published in this series may include views on policy, but the institute itself takes no institutional policy positions. The IZA research network is committed to the IZA Guiding Principles of Research Integrity.

The Institute for the Study of Labor (IZA) in Bonn is a local and virtual international research center and a place of communication between science, politics and business. IZA is an independent nonprofit organization supported by Deutsche Post Foundation. The center is associated with the University of Bonn and offers a stimulating research environment through its international network, workshops and conferences, data service, project support, research visits and doctoral program. IZA engages in (i) original and internationally competitive research in all fields of labor economics, (ii) development of policy concepts, and (iii) dissemination of research results and concepts to the interested public.
\end{abstract}

IZA Discussion Papers often represent preliminary work and are circulated to encourage discussion. Citation of such a paper should account for its provisional character. A revised version may be available directly from the author. 
IZA Discussion Paper No. 7776

November 2013

\section{ABSTRACT}

\section{The Cyclical Behaviour of Employers' Monopsony Power and Workers' Wages}

This paper investigates the behaviour of employers' monopsony power and workers' wages over the business cycle. Using German administrative linked employer-employee data for the years 1985-2010 and an estimation framework based on duration models, we construct a time series of the firm-level labour supply elasticity and estimate its relationship to the aggregate unemployment rate. In line with theory, we find that firms possess more monopsony power during economic downturns, which shows to be robust to controlling for time-invariant unobserved worker heterogeneity. We also document that cyclical changes in workers' entry wages are of similar magnitude as those predicted under monopsonistic wage setting, suggesting that monopsony power should not be neglected when analysing wage cyclicality.

JEL Classification: J42, J31

Keywords: monopsony power, business cycle, entry wages

Corresponding author:

Elke Jahn

Institute of Employment Research (IAB)

Regensburger Str. 104

90478 Nuremberg

Germany

E-mail: Elke.Jahn@iab.de

\footnotetext{
*We are grateful to Ali Athmani and Cerstin Rauscher for providing the data. For helpful comments and suggestions we would like to thank Michael Oberfichtner and participants in the RWI research seminar. We also gratefully acknowledge financial support from the Fritz Thyssen Foundation.
} 


\section{Introduction}

Lately, a number of studies has emerged that investigate the extent of monopsony power in the labour market (Ashenfelter et al., 2010). Other than classic accounts that saw employer concentration as the source of monopsony power, the recent literature makes clear that employers may readily possess marked wage-setting power in labour markets consisting of many competing firms. Potential reasons include search frictions, mobility costs, or job differentiation, all of which impede workers' responsiveness to wages. This causes the labour supply curve to the single firm to be upward-sloping, rather than being horizontal as under perfect competition (Boal and Ransom, 1997).

To assess the empirical relevance of monopsony power, a growing literature tries to estimate the firm-level labour supply elasticity (Manning, 2003; Barth and Dale-Olsen, 2009; Falch, 2010, 2011; Hirsch et al., 2010; Ransom and Oaxaca, 2010; Ransom and Sims, 2010; Staiger et al., 2010; Booth and Katic, 2011; Hirsch and Jahn, 2012, Depew and Sørensen, 2013; Hotchkiss and Quispe-Agnoli, 2013; Webber, 2013a b). The vast majority of these studies employ an estimation framework proposed by Manning (2003) that relies on a simple model of dynamic monopsony in which search frictions cause workers' labour supply to the firm to be imperfectly elastic. Imposing the structure of Burdett and Mortensen's (1998) search model and a steady-state assumption, these studies estimate the firm-level labour supply elasticity from the wage responsiveness of firms' labour flows. Overall, the resulting estimates of the elasticity turn out to be far from infinite, suggesting a non-trivial degree of monopsony power in the labour market (for a recent survey, see Manning, 2011).

Up to now, however, there is no evidence on the evolvement of employers' market power over the business cycle, with the notable exception of a recent study by Depew and Sørensen (2013). Yet, particularly monopsony power due to search frictions should be less felt by workers during economic upturns with many outside offers available to them compared to economic downturns with lingering outside opportunities. 1 Moreover,

1 Depew and Sørensen (2013) discuss this point in detail within Burdett and Mortensen s (1998) equilibrium search model and show that the firm-level labour supply elasticity is indeed lower in labour markets with a decreased job offer arrival rate and/or an increased job destruction rate. 
during bad times workers' preference for job security might induce them to be less wagedriven than during good times. We therefore expect the firm-level elasticity to move procyclically. Refining Manning s estimation approach by allowing for a non-stationary environment, Depew and Sørensen investigate the cyclical behaviour of the firm-level labour supply elasticity with data stemming from two large American firms for the years 1919-1940. They find that the elasticity is indeed moving procyclically. Estimates range from -0.5 during the Great Depression to 5.9 in the subsequent recovery and thus imply a substantially varying monopsonistic markdown on wages of 15 to 100 per cent.

We build on Depew and Sørensen (2013) by investigating the cyclical behaviour of the firm-level labour supply elasticity for West Germany using linked administrative employer-employee data encompassing the years 1985-2010. In doing so we improve on their contribution in several ways: (i) Our data set is based on a current representative sample of all workers covered by the German social security system and thus complements their findings based on two large firms' personnel files from the pre-war U.S. with recent results for a whole economy based on high-quality administrative data. (ii) The richness of our data set allows us to explicitly take into account hired workers' previous and separating workers' subsequent labour market status. We are thus able to use a more sophisticated estimation approach distinguishing transitions from/to employment from those from/to non-employment. (iii) The high frequency and long time span of our data further permits us to use hazard rate models on an inflow sample of job spells thereby accounting for left-truncation and right-censoring of job durations and unobserved time-invariant worker heterogeneity. (iv) What is more, the richness of our data allows us to confront the cyclical movements in employers' monopsony power with observed fluctuations in workers' wages and thus to relate predicted cyclical wage changes under monopsonistic wage setting to actual changes.

The remainder of this paper is organised as follows: Section 2 sets up our econometric approach that will be used to estimate the firm-level labour supply elasticity and its cyclical fluctuations from job transition data. The data used are described in Section 3 . Section 4 presents and discusses our results, and Section 5 concludes. 


\section{Econometric approach}

\subsection{Estimating the firm-level labour supply elasticity}

The starting point of our econometric approach, which has been pioneered by Manning (2003, pp. 96-104) and refined later by Depew and Sørensen (2013) and Webber (2013a b), is a simple dynamic monopsony model for the labour supply to the firm. Consider a firm paying some wage $w_{t}$ at time period $t \in \mathbb{N}$. We model the labour supply to this firm as

$$
L_{t}=L_{t}\left(w_{t}, L_{t-1}\right)=R^{e}\left(w_{t}\right)+R^{n}\left(w_{t}\right)+\left[1-s^{e}\left(w_{t}\right)-s^{n}\left(w_{t}\right)\right] L_{t-1},
$$

where $R^{e}>0\left(R^{n}>0\right)$ denotes the number of recruits hired from employment (nonemployment) with $R^{e \prime}, R^{n^{\prime}}>0$ and $0<s^{e}<1\left(0<s^{n}<1\right)$ the separation rate to employment (non-employment) with $s^{e^{\prime}}, s^{n^{\prime}}<0$ and the initial labour supply is some $L_{0}>0$. Define $\gamma_{t} \equiv \frac{L_{t}-L_{t-1}}{L_{t-1}}$ as the growth rate of the firm's labour supply from $t-1$ to t. Then, rearranging of (1) yields

$$
L_{t}\left(w_{t}\right)=\frac{\left(\gamma_{t}+1\right)\left[R^{e}\left(w_{t}\right)+R^{n}\left(w_{t}\right)\right]}{s^{e}\left(w_{t}\right)+s^{n}\left(w_{t}\right)+\gamma_{t}} .
$$

Taking $\operatorname{logs}$, differentiating with respect to $w_{t}$, and multiplying by $w_{t}$ give

$$
\varepsilon_{L w}=\theta_{R}\left(w_{t}\right) \varepsilon_{R w}^{e}+\left[1-\theta_{R}\left(w_{t}\right)\right] \varepsilon_{R w}^{n}-\frac{\theta_{s}\left(w_{t}\right) s^{e}\left(w_{t}\right)}{s^{e}\left(w_{t}\right)+\theta_{s}\left(w_{t}\right) \gamma_{t}} \varepsilon_{s w}^{e}-\frac{\left[1-\theta_{s}\left(w_{t}\right)\right] s^{n}\left(w_{t}\right)}{s^{n}\left(w_{t}\right)+\left[1-\theta_{s}\left(w_{t}\right)\right] \gamma_{t}} \varepsilon_{s w}^{n}
$$

where $\varepsilon_{s w}^{e}\left(\varepsilon_{s w}^{n}\right)$ denotes the separation rate elasticity to employment (non-employment), $\varepsilon_{R w}^{e}\left(\varepsilon_{R w}^{n}\right)$ the recruitment elasticity from employment (non-employment), $\theta_{R}=\frac{R^{e}}{R^{e}+R^{n}}$ the share of hires from employment, and $\theta_{s}=\frac{s^{e}}{s^{e}+s^{n}}$ the share of separations to employment.

Equation (3) simplifies once we impose more structure on the model. Following the previous literature we make use of Burdett and Mortensen's (1998) equilibrium search model. In this model, employed workers search on the job drawing job offers from the wage distribution $F$ at a constant rate $\lambda$ and are assumed to change employers whenever the offered wage is larger than the current one. Hence, the separation rate to employment 
and the recruits from employment are given by

$$
\begin{aligned}
s^{e}\left(w_{t}\right) & =\lambda\left[1-F\left(w_{t}\right)\right], \\
R^{e}\left(w_{t}\right) & =\lambda \int_{\underline{w}}^{w_{t}} L_{t}(x) d F(x),
\end{aligned}
$$

where $\underline{w}$ denotes workers' common reservation wage. Using (4) the separation rate elasticity to employment is given by

$$
\varepsilon_{s w}^{e}=-\frac{\lambda F^{\prime}\left(w_{t}\right) w_{t}}{s^{e}\left(w_{t}\right)}
$$

Making use of (2), (5), and (6) the recruitment elasticity from employment becomes

$$
\varepsilon_{R w}^{e}=\frac{\lambda L_{t}\left(w_{t}\right) F^{\prime}\left(w_{t}\right) w_{t}}{R^{e}\left(w_{t}\right)}=-\frac{s^{e}\left(w_{t}\right) L_{t}\left(w_{t}\right)}{R^{e}\left(w_{t}\right)} \varepsilon_{s w}^{e}=-\frac{\theta_{s}\left(w_{t}\right)\left(\gamma_{t}+1\right) s^{e}\left(w_{t}\right)}{\theta_{R}\left(w_{t}\right)\left[s^{e}\left(w_{t}\right)+\theta_{s}\left(w_{t}\right) \gamma_{t}\right]} \varepsilon_{s w}^{e} .
$$

Next, turn to the recruits from non-employment. These are given by

$$
R^{n}\left(w_{t}\right)=\frac{1-\theta_{R}\left(w_{t}\right)}{\theta_{R}\left(w_{t}\right)} R^{e}\left(w_{t}\right)
$$

Taking logs, differentiating with respect to $w_{t}$, and multiplying by $w_{t}$ yield

$$
\varepsilon_{R w}^{n}=\varepsilon_{R w}^{e}-\frac{\theta_{R}^{\prime}\left(w_{t}\right) w_{t}}{\left[1-\theta_{R}\left(w_{t}\right)\right] \theta_{R}\left(w_{t}\right)}=\varepsilon_{R w}^{e}-\frac{\varepsilon_{\theta w}^{R}}{1-\theta_{R}\left(w_{t}\right)}
$$

with $\varepsilon_{\theta w}^{R}$ denoting the wage elasticity of the share of recruits hired from employment. Combining (3), (7), and (9) we get

$$
\varepsilon_{L w}=-\underbrace{\frac{\theta_{s}\left(w_{t}\right)\left[\gamma_{t}+1+\theta_{R}\left(w_{t}\right)\right] s^{e}\left(w_{t}\right)}{\theta_{R}\left(w_{t}\right)\left[s^{e}\left(w_{t}\right)+\theta_{s}\left(w_{t}\right) \gamma_{t}\right]}}_{\equiv a} \varepsilon_{s w}^{e}-\underbrace{\frac{\left[1-\theta_{s}\left(w_{t}\right)\right] s^{n}\left(w_{t}\right)}{s^{n}\left(w_{t}\right)+\left[1-\theta_{s}\left(w_{t}\right)\right] \gamma_{t}}}_{\equiv b} \varepsilon_{s w}^{n}-\varepsilon_{\theta w}^{R},
$$

which allows us to estimate the firm-level labour supply elasticity from the two separation rate elasticities, $\varepsilon_{s w}^{e}$ and $\varepsilon_{s w}^{n}$, their weights, $a$ and $b$, and the wage elasticity of the share of recruits hired from employment.$^{2}$

2 Note that equation $\sqrt{10}$ differs from the equation estimated by Webber $(2013 a b)$. The reason for this is that Webber's equation (9) imposes $L_{t}=\left(\gamma_{t}+1\right) R^{e}\left(w_{t}\right) /\left[\gamma_{t}+s_{t}^{e}\left(w_{t}\right)\right]$, thereby ignoring 
Note that equation 10 nests the simpler approaches used in the earlier literature to estimate the firm-level labour supply elasticity: (i) Assuming a steady-state environment with constant employment for all firms, that is $\theta(w) \equiv \theta_{R}(w) \equiv \theta_{s}(w)$ and $\gamma_{t} \equiv 0$, equation (10) simplifies to

$$
\varepsilon_{L w}=-[1+\theta(w)] \varepsilon_{s w}^{e}-[1-\theta(w)] \varepsilon_{s w}^{n}-\varepsilon_{\theta w}^{R}
$$

as in Manning (2003, p. 100). (ii) Restricting to an environment without transitions from and to non-employment instead, but allowing for changes in the firm's employment, i.e. $\theta^{R}\left(w_{t}\right) \equiv \theta^{s}\left(w_{t}\right) \equiv 1$, equation 10 becomes

$$
\varepsilon_{L w}=-\frac{\left(\gamma_{t}+2\right) s^{e}\left(w_{t}\right)}{s^{e}\left(w_{t}\right)+\gamma_{t}} \varepsilon_{s w}^{e}
$$

which corresponds to Depew and Sørensen's (2013) equation (2). (iii) Additionally imposing a steady state with constant employment, i.e. $\gamma_{t} \equiv 0$, we get

$$
\varepsilon_{L w}=-2 \varepsilon_{s w}^{e}
$$

as in Manning (2003, p. 98).

\subsection{Econometric specification}

To estimate the firm-level labour supply elasticity over the business cycle using equation (10), we have to estimate the cyclical movement of five components: (i) the separation rate elasticity to employment $\varepsilon_{s w}^{e}$ and (ii) its weight $a$, (iii) the separation rate elasticity to non-employment $\varepsilon_{s w}^{n}$ and (iv) its weight $b$, and (v) the wage elasticity of the share of recruits from employment $\varepsilon_{\theta w}^{R}$. In the following, we will use the aggregate unemployment rate lagged by a year as a measure of the business cycle as workers' transition behaviour is unlikely to respond immediately to changes in the labour market situation.

To arrive at estimates of the separation rate elasticities to employment and non-

the impact of recruits coming from and incumbent workers separating to non-employment on the firm-level labour supply (see equation 2 for comparison). 
employment, we follow Hirsch et al. (2010) and model the separation rates of job spell $i$ belonging to worker $m(i)$ as exponential models

$$
s_{i}^{r}\left(\mathbf{x}_{i}^{r}(t), v_{m(i)}^{r}\right)=\exp \left(\mathbf{x}_{i}^{r}(t)^{\prime} \boldsymbol{\beta}^{r}\right) v_{m(i)}^{r}
$$

with $r=e, n$, a vector of time-varying covariates $\mathbf{x}_{i}^{r}(t)$, a corresponding vector of coefficients $\boldsymbol{\beta}^{r}$, and unobserved worker heterogeneity $v_{m(i)}^{r}$, which is assumed to follow a gamma distribution (as put forward by Abbring and van den Berg, 2007) $!^{3}$ Note that by specifying separation rates as exponential models, we do not control for job tenure (i.e. we impose a constant baseline hazard on the model and thus restrict the separation rate to show no duration dependence). Of course, this puts a severe restriction on the models. Yet, we follow Manning (2003, p. 103) in arguing that under monopsony firms pay higher wages in order to reduce separations and increase tenure. Controlling for tenure would fail to attribute this indirect effect on the firm's labour supply to wages and therefore yield a downward bias (in absolute value) in the estimated separation rate elasticities.4 To estimate the separation elasticities, we include the log wage and its interaction with the lagged unemployment rate $u_{i}(t)$ as covariates in (14). So the respective separation rate elasticity is given by $\varepsilon_{s w}^{r}=\beta_{w}^{r}+\beta_{u w}^{r} \times u_{i}(t)$, and the estimated $\beta_{u w}^{r}$ informs us on its cyclicality.

The wage elasticity of the share of recruits hired from employment is estimated from a random-effects logit model for the probability that a recruit comes from employment (as opposed to non-employment)

$$
\operatorname{Pr}\left[y_{i}=1 \mid \mathbf{x}_{i}, v_{m(i)}\right]=\Lambda\left(\mathbf{x}_{i}^{\prime} \boldsymbol{\beta}+v_{m(i)}\right)
$$

where notation follows the same rules as before, $y_{i}$ is an indicator for a hire from

3 Assuming conditional independence of the separation probabilities to employment and nonemployment Manning (2003, pp. 100/101) shows that they can be estimated separately by two univariate hazard rate models. When estimating the separation rate to non-employment all job spells are used. When estimating the separation rate to employment, however, only those job spells that do not end in non-employment are considered.

4 This is exactly what is found in a later check of robustness in which we use stratified Cox models that allow for a worker-specific baseline hazard and thereby control for both time-invariant unobserved worker heterogeneity and job tenure. 
employment, $\Lambda$ denotes the c.d.f. of a standard logistic distribution, and unobserved worker heterogeneity $v_{m}$ is Gaussian. Again, we include the log wage and its interaction with the unemployment rate as covariates in (15). As can be easily shown, $\beta_{w}+\beta_{u w} \times u_{i}$ gives the wage elasticity of the share of recruits hired from employment divided by $1-\theta_{R}$.

Finally, the weights of the separation rate elasticities to employment and nonemployment, $a$ and $b$, are estimated from the data. That is, for every period $a$ and $b$ are calculated using the period sample averages of $\theta_{s}, \theta_{R}, s^{e}, s^{n}$, and $\gamma_{t}$.

Together, the period estimates of $\varepsilon_{s w}^{e}, \varepsilon_{n w}^{n}, \varepsilon_{\theta w}^{R}, a$, and $b$ allow us to construct a time series of the firm-level labour supply elasticity. In a next step of analysis, we relate this time series to the lagged unemployment rate in the economy to see by how much the elasticity is moving over the business cycle. In a last step, we compare cyclical fluctuations in the elasticity to those in workers' wages to gain insight into the potential economic relevance of cyclical changes in employers' monopsony power.

\section{Data}

To put this approach into practice, we need detailed high-frequency data on job lengths, preceding and subsequent jobs and periods of non-employment, as well as on workers and employers over a long period of time, ideally encompassing several business cycles. For our purpose, we combine two administrative data sets for the period 1985-2010: the Integrated Employment Biographies (IEB) and a quarterly version of the Establishment History Panel (BHP) provided by the Institute for Employment Research (IAB).

The data on job lengths (on a daily basis), transitions, wages (deflated by the consumer price index), and worker characteristics come from a 5 per cent random sample of the IEB. The IEB comprises all wage and salary employees registered with the German social security system, where about 80 per cent of all people employed in Germany are covered by the system. $5^{5}$ Since the information contained is used to calculate social security contributions, the data set is highly reliable and especially useful for analyses taking wages and job durations into account.

$5 \quad$ For details on the IEB, see $\overline{\text { Jacobebbinghaus and Seth }}(2007)$. 
Information on employers comes from a quarterly version of the BHP which again consists of data from the German social insurances that are this time aggregated at the end of each quarter $\sqrt[6]{6}$ It not only contains information on plants' workforce composition and size but also on plant closures. This allows us to calculate the geometric mean of plants' growth rate, where we exclude plants (and job spells in these plants) during their founding and closing year.7

Although our data contain observations for East German workers from 1992 onwards, restricting our analysis to the post-unification period would markedly reduce our period of observation and thus the scope of our investigation. Moreover, including East German data for the 1990s would mix up business cycle effects and those effects stemming from the transition of a socialist planned economy to a market economy. We will thus focus our analysis throughout on individuals working in West Germany (excluding Berlin) during the period 1985-2010 and further restrict it to males aged 18-55 years to circumvent selectivity issues regarding female employment and early retirement.

The merged data set allows us to build up an inflow sample of job spells starting between 1985 and 2010 taking into account workers' previous labour market status, the job length, and - provided the job ended during our period of observation - workers' subsequent labour market status. In the following, we follow our theoretical model and distinguish two labour market status: employment and non-employment. Consequently, a job may end with a transition to employment, which refers to a new job with another employer (i.e. a plant with a different plant identifier), or with a transition to nonemployment, which refers to a subsequent spell in registered unemployment or no spell in the data at all 8 The latter either implies that the individual has changed to nonemployment without receiving unemployment benefits or that he has become, for instance, a self-employed worker not included in the data set. While our data do not enable us to disaggregate this category of unknown destination, information from other German data

$6 \quad$ For details on the BHP, see $\overline{\text { Spengler }}(2009)$.

$7 \quad$ Note that plant size does not comprise marginally employed workers as these are not consistently included in our data. Besides, we drop job spells in those very few plants that have implausibly large growth rates (i.e. larger than 100,000 per cent) or plant size zero.

8 Separations are ignored if the employee is recalled by the same plant within three months. 
sets suggests that the vast majority of employees in this category have indeed moved to non-employment 9

Whereas information on job spells and daily gross wages included in the data are highly reliable, the data include no detailed information on the number of hours worked. Also, wages are top-coded at the social security contribution ceiling, which affects 9.6 per cent of our observations. To deal with the first drawback, we restrict our analysis to full-time workers. To cope with the second, we exclude job spells with wages above the ceiling. Besides, information on workers' education is provided by employers and therefore inconsistent or missing for some workers. To alleviate this problem, we impute the missing information on education by employing a procedure proposed by Fitzenberger et al. (2006) that allows inconsistent education information to be corrected. After applying this imputation procedure, only about 1.5 per cent of the job spells are dropped due to missing or inconsistent information on education.

As can be seen from Table 1, our final data set comprises an inflow sample of 2,588,212 job spells belonging to 852,202 workers employed by 657,811 plants. Out of these jobs, 41.7 per cent start from employment and 58.3 from non-employment. Similarly, out of the

Table 1: Job spells and transitions

\begin{tabular}{lr}
\hline Job spells & $2,588,212$ \\
Workers & 852,202 \\
Plants & 657,811
\end{tabular}

Hires from employment

Hires from non-employment $\quad 1,508,048$

Separations to employment $\quad 1,034,253 \quad(40.0)$

Separations to non-employment $\quad 1,262,451 \quad$ (48.8)

Right-censored job spells $\quad 291,508 \quad(11.3)$

Notes: The data sets used are a 5 per cent random sample of the IEB and a quarterly version of the BHP, 1985-2010. Percentages in parentheses.

$9 \quad$ See, for example, Bartelheimer and Wieck 2005$)$ for a transition matrix between employment and non-employment based on the German Socio-Economic Panel that allows stratification of the 'unknown' category into detailed categories. 
2,296,704 jobs terminated during our observation window, 1,034,253 or 45.0 per cent end with a separation to employment and 1,262,451 or 55.0 per cent end with a transition to non-employment. For further descriptives on our sample, see Appendix Table A.1.

\section{Results}

\subsection{Cyclicality of the firm-level labour supply elasticity}

To arrive at estimates of the firm-level labour supply elasticity, we first of all estimate exponential models for the separation rates to employment and non-employment and a random-effects logit model for the probability that a recruit is hired from employment as opposed to non-employment. This provides us with estimates for the separation rate elasticities to employment and non-employment and the wage elasticity of the share of recruits hired from employment. All these models include individuals' log wage and the interaction term of the log wage and the lagged West German unemployment rate as main regressors to allow for varying elasticities over the business cycle. We further include six age, two education, and ten occupation dummies and an indicator for an immigrant worker to control for individual characteristics 10 As plant controls we add four plant size dummies, the shares of low-skilled, high-skilled, female, immigrant, and part-time workers in the plant's workforce, the median age of the plant's workers, and 24 sector dummies. All estimations further include macro controls, namely year and quarter of job entry dummies, dummies for the size of the region the firm is located in (i.e. rural, urban, or metropolitan), and the lagged aggregate unemployment rate.

Fitting these models, the main results of which are presented in Table 2, we find that all three elasticities vary statistically significantly over the business cycle: If the unemployment rate is high, both the separation rate elasticities to employment and nonemployment are lower in absolute value (though the effect on the latter is very small in magnitude) whereas the wage elasticity of the share of recruits hired from employment gets larger. As can be readily seen from equation 100 , every change in isolation as well as

$\overline{10}$ We follow Brücker and Jahn $(2011)$ and count as immigrants all workers with non-German citizenship and so-called ethnic German immigrants, who possess German citizenship. 
Table 2: Separation rate and recruitment elasticities
Exponential model for separation rate to employment
$\log$ wage
$-1.778^{* *}(0.019)$
log wage $\times$ lagged unemployment rate
$0.041^{* *}(0.002)$
Exponential model for separation rate to non-employment
log wage
$-1.631^{* *}(0.016)$
log wage $\times$ lagged unemployment rate
$0.007^{* *}(0.002)$
Logit model for hiring probability from employment
\begin{tabular}{ll} 
log wage & $0.877^{* *}(0.026)$ \\
log wage $\times$ lagged unemployment rate & $0.042^{* *}(0.003)$ \\
\hline
\end{tabular}
Notes: The data sets used are a 5 per cent random sample of the IEB and a quarterly version of the BHP, 1985-2010. Standard errors clustered at person level in parentheses. **/* denotes statistical significance at the $1 / 5$ per cent level. Covariates included in the estimations are two education, six age, and three plant size dummies, quarter and year of entry dummies, dummies indicating the size of the regional labour market, for an immigrant worker, one-digit occupation, and two-digit industry, the shares of low- skilled, high-skilled, female, immigrant, and part-time workers in the plant's workforce, the median age of its workforce, and the lagged aggregate unemployment rate. Detailed results are available on request.

all changes together depress the firm-level labour supply elasticity and thus raise firms' monopsony power.

To construct a time series of the firm-level labour supply elasticity, we next have to estimate the weights of the two separation rate elasticities in equation $(10), a$ and $b$, from the data by combining quarterly information on employment flows and plant growth rates. From the estimates of the separation rate and recruitment elasticities and the weights we obtain a quarterly time series of the firm-level labour supply elasticity for the years 19852010. As is clear from Table 3 summarising our estimates, the firm-level labour supply elasticity is varying markedly over our period of observation with estimates ranging from 1.17 to 2.84 (and thus well within the range of the previous steady-state estimates surveyed by Manning, 2011, Table 7). The aggregate unemployment rate also varies considerably from 5.8 to 11.8 per cent. A plot of both the elasticity and the unemployment rate time series (see Figure 1) is suggestive of a substantial procyclicality of the elasticity. Yet, the plot also reveals a strong seasonality in the elasticity series. 
Table 3: Lagged unemployment rate and the estimated elasticities and weights

\begin{tabular}{lrrrr}
\hline & Mean & S.D. & Min & Max \\
\hline Lagged aggregate unemployment rate (per cent) & 8.705 & 1.286 & 5.800 & 11.800 \\
Labour supply elasticity at firm level $\left(\hat{\varepsilon}_{L w}\right)$ & 2.044 & 0.326 & 1.166 & 2.835 \\
Separation rate elasticity to employment $\left(\hat{\varepsilon}_{s w}^{e}\right)$ & -1.424 & 0.052 & -1.542 & -1.298 \\
Separation rate elasticity to non-employment $\left(\hat{\varepsilon}_{s w}^{n}\right)$ & -1.571 & 0.009 & -1.592 & -1.550 \\
Elasticity of the share of hires from employment $\left(\hat{\varepsilon}_{\theta w}^{R}\right)$ & 0.718 & 0.090 & 0.560 & 0.943 \\
Weight of separation elasticity to employment $(\hat{a})$ & 1.370 & 0.164 & 0.692 & 1.841 \\
Weight of separation elasticity to non-employment $(\hat{b})$ & 0.516 & 0.100 & 0.288 & 0.755 \\
Observations (quarters) & \multicolumn{4}{c}{104} \\
\hline
\end{tabular}

Notes: The data sets used are a 5 per cent random sample of the IEB and a quarterly version of the BHP, 1985-2010. The separation rate and recruitment elasticities are estimated using the results from Table 2 The weights are calculated using quarterly sample averages. The firm-level labour supply elasticity is estimated using equation (10).

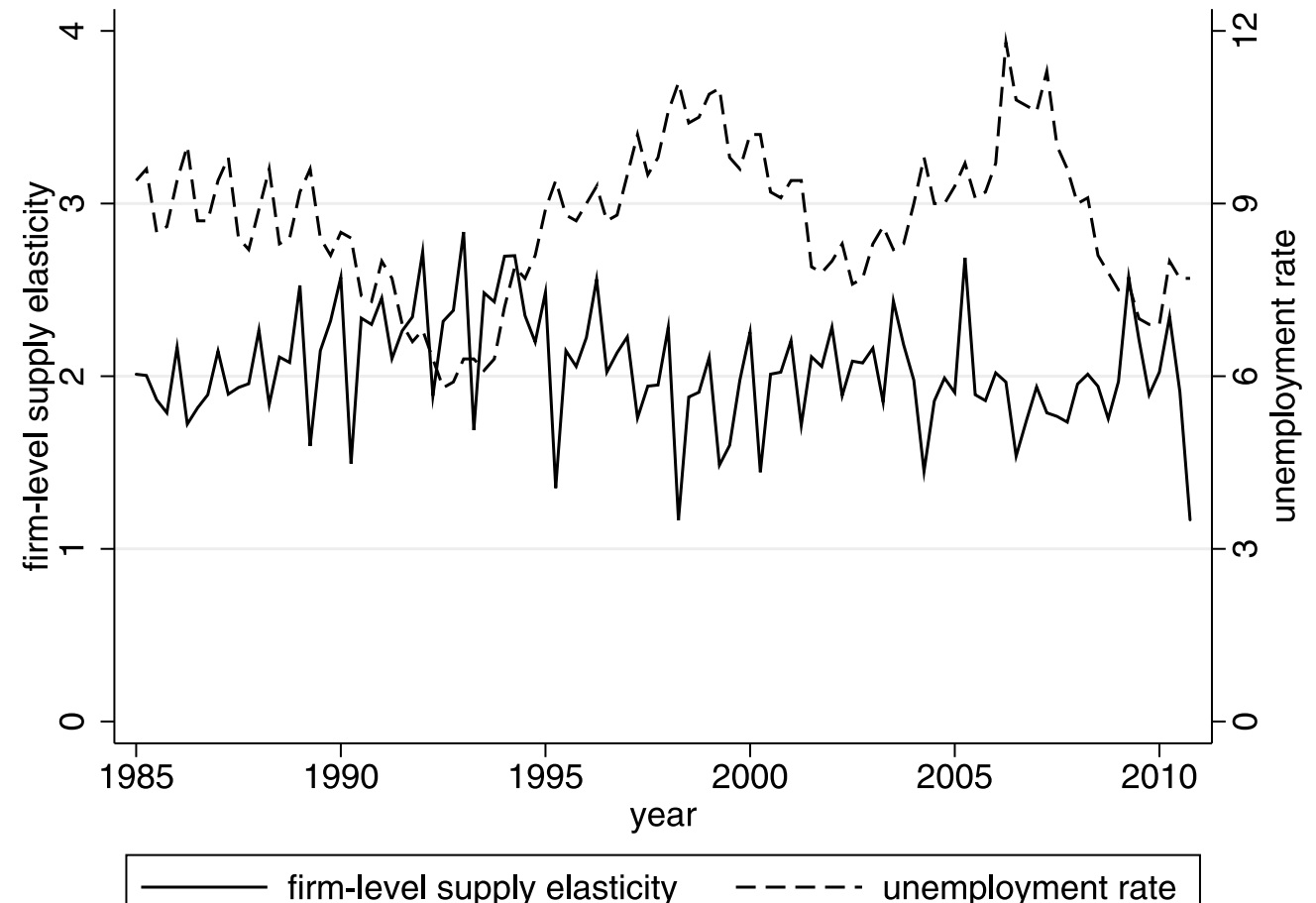

Figure 1: Lagged aggregate unemployment rate and estimated firm-level labour supply elasticity 
To get rid of the seasonality and a potential trend in the labour supply elasticity, we run some simple regressions, regressing the elasticity on the unemployment rate, a group of quarter dummies, and a quadratic time trend. As can be seen from Table 4 , there is a significantly negative correlation between the estimated labour supply elasticity and the unemployment rate that hardly changes when controlling for seasonal and trend patterns. An increase in the unemployment rate by one percentage point is associated with a decrease in the labour supply elasticity of about 0.12 .

To get an impression about the economic relevance of this number, recall that under monopsonistic wage setting workers' wage $w^{m}$ is a fraction of their marginal revenue product $\phi$ that directly depends on the firm-level labour supply elasticity,

$$
w^{m}=\frac{\varepsilon_{L w}}{\varepsilon_{L w}+1} \phi
$$

At the mean elasticity of our sample of 2.04 (see Table 3) this suggests that workers obtain just 67.1 per cent of their marginal product and thus implies a considerable extent of monopsony power. Now consider a marked economic downturn leading to an increase in the unemployment rate by, say, 2.5 percentage points. Using the results from Model 3 in Table 4, this decreases the elasticity by 0.29 to 1.75 , and workers are thus expected

Table 4: Firm-level labour supply elasticity and lagged unemployment rate when controlling for seasonality and trend

\begin{tabular}{lccc}
\hline & Model 1 & Model 2 & Model 3 \\
\hline Unemployment rate & $-0.114^{* *}(0.018)$ & $-0.116^{* *}(0.016)$ & $-0.116^{* *}(0.018)$ \\
2nd quarter (dummy) & & $-0.318^{* *}(0.108)$ & $-0.319^{* *}(0.111)$ \\
3rd quarter (dummy) & & $-0.262^{* *}(0.050)$ & $-0.262^{* *}(0.045)$ \\
4th quarter (dummy) & & $-0.295^{* *}(0.049)$ & $-0.295^{* *}(0.041)$ \\
Year & & & $0.028^{* *}(0.010)$ \\
Year ${ }^{2} / 100$ & & $-0.125^{* *}(0.041)$ \\
Constant & $2.044^{* *}(0.025)$ & $2.263^{* *}(0.051)$ & $2.180^{* *}(0.062)$ \\
\hline
\end{tabular}

Notes: The data sets used are a 5 per cent random sample of the IEB and a quarterly version of the BHP, 1985-2010. The regression sample is described in Table 3 . The regressand is the firm-level labour supply elasticity. Newey-West standard errors (with lag length four) in parentheses. $* * / *$ denotes statistical significance at the $1 / 5$ per cent level. The lagged aggregate unemployment rate is centred around its mean. 
to receive only 63.7 per cent of their marginal product. In other words, workers' wages are expected to decrease by 5.2 per cent if employers make full use of their additional monopsony power over their workers. Our results therefore are in line with theory in suggesting that the firm-level labour supply elasticity moves procyclically and so in an economically significant way.

\subsection{Cyclicality of firms' monopsony power and workers' wages}

Although we have identified substantial and varying monopsony power, it remains unclear whether firms actually exploit cyclical changes in their monopsony power by raising wages during economic upturns and lowering them when economic activity is deteriorating. While employers' are unlikely to (substantially) change ongoing wages, due to institutional constraints like collective bargaining or implicit contracts, entry wages have shown to be considerably responsive to the business cycle in Germany (for a survey and recent evidence, see Stüber, 2013). To relate our findings on the procyclicality of the firm-level supply elasticity to cyclical fluctuations in workers' wages, we run some standard wage regressions regressing workers' entry wages on the lagged aggregate unemployment rate and all the covariates included in the hazard rate and logit models controlling for personal and firm characteristics. The results shown in Table 5 confirm that entry wages respond significantly to changes in the unemployment rate. ${ }^{11}$ In a standard OLS wage regression, an increase in the unemployment rate by one percentage point is associated with a significant decrease in the entry wage of about 1.5 per cent. When also including worker fixed effects, this effect reduces somewhat to 1.2 per cent but is still sizeable.

As we previously saw, our results imply that under pure monopsonistic wage setting a severe economic downturn increasing the unemployment rate by 2.5 percentage points is expected to reduce workers' wages by 5.2 per cent. Our wage regressions document that workers' entry wages would sink by 3.0-3.8 per cent if such an increase in unemployment were to occur. Hence, cyclical changes in employers' wage-setting power are able to

11 Note that, in line with our expectations, running similar regressions including incumbent workers' wages shows that wages are almost unresponsive to changes in the unemployment rate. The effect of the unemployment rate is only about a tenth of the effect on entry wages. 
Table 5: Entry wage regressions

\begin{tabular}{lcc}
\hline & OLS & Person FE \\
\hline Lagged unemployment rate & $-0.015^{* *}(0.001)$ & $-0.012^{* *}(0.001)$ \\
Immigrant (dummy) & $-0.050^{* *}(0.001)$ & \\
Medium-skilled (dummy) & $0.118^{* *}(0.001)$ & $0.044^{* *}(0.001)$ \\
High-skilled (dummy) & $0.280^{* *}(0.002)$ & $0.272^{* *}(0.002)$ \\
Age 18-25 years (dummy) & $-0.099^{* *}(0.001)$ & $-0.025^{* *}(0.001)$ \\
Age 31-35 years (dummy) & $0.055^{* *}(0.001)$ & $-0.016^{* *}(0.001)$ \\
Age 36-40 years (dummy) & $0.082^{* *}(0.001)$ & $-0.069^{* *}(0.002)$ \\
Age 41-45 years (dummy) & $0.092^{* *}(0.001)$ & $-0.144^{* *}(0.002)$ \\
Age 46-50 years (dummy) & $0.091^{* *}(0.001)$ & $-0.236^{* *}(0.003)$ \\
Age 51-55 years (dummy) & $0.079^{* *}(0.002)$ & $-0.340^{* *}(0.004)$ \\
Plant size 11-50 (dummy) & $0.062^{* *}(0.001)$ & $0.047^{* *}(0.001)$ \\
Plant size 51-200 (dummy) & $0.073^{* *}(0.001)$ & $0.053^{* *}(0.001)$ \\
Plant size 201-1000 (dummy) & $0.124^{* *}(0.001)$ & $0.089^{* *}(0.001)$ \\
Plant size > 1000 (dummy) & $0.166^{* *}(0.001)$ & $0.120^{* *}(0.001)$ \\
Share of low-skilled workers & $-0.085^{* *}(0.001)$ & $-0.060^{* *}(0.001)$ \\
Share of high-skilled workers & $0.373^{* *}(0.003)$ & $0.249^{* *}(0.003)$ \\
Share of female workers & $-0.132^{* *}(0.002)$ & $-0.105^{* *}(0.001)$ \\
Share of immigrant workers & $-0.117^{* *}(0.002)$ & $-0.061^{* *}(0.002)$ \\
Share of part-time workers & $-0.067^{* *}(0.002)$ & $-0.050^{* *}(0.002)$ \\
Median age of workforce / 100 & $0.511^{* *}(0.004)$ & $0.397^{* *}(0.004)$ \\
Observations & & $2,588,212$ \\
\hline
\end{tabular}

Notes: The data sets used are a 5 per cent random sample of the IEB and a quarterly version of the BHP, 1985-2010. The regressand is the log gross daily wage in the first observation of every job spell. Standard errors clustered at the person level in parentheses. ${ }^{*} / *$ denotes statistical significance at the $1 / 5$ per cent level. Further covariates included are dummies indicating the size of the regional labour market, dummies for one-digit occupation and two-digit industry, as well as quarter and year dummies.

account for the procyclicality of workers' wages, though admittedly we cannot be sure that observed wage changes actually reflect cyclical changes in monopsony power. Nevertheless, our back-of-the-envelope calculation makes clear that the procyclicality of the firm-level labour supply elasticity is of the magnitude needed to generate observed wage changes if employers were to fully exploit their wage-setting power. This contrasts with the earlier contribution by Depew and Sørensen (2013) who found cyclical fluctuations of the monopsonistic markdown that are magnitudes higher than those of workers' wages. 
One has to bear in mind, however, that Depew and Sørensen's study utilises pre-war data from two U.S. firms' personnel files that comprise the unprecedented slump during and the strong recovery following the Great Depression and thus a period of unique economic turmoil unlikely to compare to our period of observation.

\subsection{Robustness to unobserved worker heterogeneity}

One legitimate concern regarding our findings is that transiting workers may differ considerably in terms of unobserved characteristics depending on the current state of the business cycle. As a case in point, a worker changing employers during bad times is arguably of much higher quality than a worker doing so during a boom. Therefore, our findings might suffer from bias if wages and workers' transition behaviour are correlated with unobserved worker quality. To scrutinise the impact of unobserved worker heterogeneity on our findings, we redo our analysis estimating separation rate and recruitment elasticities from models that control for unobserved time-invariant worker heterogeneity allowing this heterogeneity to be correlated with observed covariates.

More precisely, separation rate elasticities are estimated from stratified Cox models. In these models, we specify the baseline hazard to be some arbitrary worker-specific function of job tenure thereby including unobserved worker heterogeneity. Adopting the stratified partial likelihood estimator allows us to sweep out the worker-specific baseline hazard without the need of identifying it and thus to estimate the covariates' coefficients while controlling for unobserved worker heterogeneity in a similarly convenient way as with the within estimator in linear fixed-effects models (cf. Ridder and Tunall, 1999). That said, estimating stratified Cox models implies that we control for job tenure as the worker-specific baseline hazard drops out of the partial likelihood function without being constrained to be constant over job tenure. As discussed in Section 2.2, controlling for tenure misses the indirect effect of wages on the firm-level labour supply through job tenure. We should therefore expect estimated separation rate elasticities, and thus the estimates of the firm-level labour supply elasticity, to be considerably lower than in our previously estimated exponential models that do not control for job tenure. Finally, 
Table 6: Separation rate and recruitment elasticities when controlling for unobserved time-invariant worker heterogeneity

Stratified Cox model for separation rate to employment

$\log$ wage

$-1.626^{* *}(0.034)$

log wage $\times$ lagged unemployment rate

$0.067^{* *}(0.004)$

Stratified Cox model for separation rate to non-employment

log wage

log wage $\times$ lagged unemployment rate

Conditional logit model for hiring probability from employment

log wage

$0.565^{* *}(0.033)$

log wage $\times$ lagged unemployment rate

$0.050 * *(0.004)$

Notes: The data sets used are a 5 per cent random sample of the IEB and a quarterly version of the BHP, 1985-2010. Standard errors clustered at person level in parentheses. **/* denotes statistical significance at the $1 / 5$ per cent level. Covariates included are the same as in Table 2. Detailed results are available on request.

Table 7: Lagged unemployment rate and estimated elasticities and weights when controlling for unobserved time-invariant worker heterogeneity

\begin{tabular}{lrrrr}
\hline & Mean & S.D. & Min & Max \\
\hline Lagged aggregate unemployment rate (per cent) & 8.705 & 1.286 & 5.800 & 11.800 \\
Labour supply elasticity at firm level $\left(\hat{\varepsilon}_{L w}\right)$ & 1.282 & 0.269 & 0.561 & 1.948 \\
Separation rate elasticity to employment $\left(\hat{\varepsilon}_{s w}^{e}\right)$ & -1.040 & 0.087 & -1.236 & -0.832 \\
Separation rate elasticity to non-employment $\left(\hat{\varepsilon}_{s w}^{n}\right)$ & -0.842 & 0.006 & -0.856 & -0.827 \\
Elasticity of the share of hires from employment $\left(\hat{\varepsilon}_{\theta w}^{R}\right)$ & 0.577 & 0.079 & 0.432 & 0.791 \\
Weight of separation elasticity to employment $(\hat{a})$ & 1.370 & 0.164 & 0.692 & 1.841 \\
Weight of separation elasticity to non-employment $(\hat{b})$ & 0.516 & 0.100 & 0.288 & 0.755 \\
Observations (quarters) & \multicolumn{3}{c}{104} \\
\hline
\end{tabular}

Notes: The data sets used are a 5 per cent random sample of the IEB and a quarterly version of the BHP, 1985-2010. The separation rate and recruitment elasticities are estimated using results analogous to those from Table 2 but using stratified Cox and conditional logit models controlling for time-invariant worker heterogeneity instead. The weights are calculated using quarterly sample averages. The firmlevel labour supply elasticity is estimated using equation 10 . 
the wage elasticity of the share of recruits hired from employment is estimated from a conditional logit model.

As can be seen from Tables 6 and 7, estimates of all the elasticities including the firmlevel labour supply elasticity are markedly lower when controlling for unobserved timeinvariant worker heterogeneity by means of stratified Cox and conditional logit models. As a consequence, employers' implied wage-setting power gets much larger. At the mean elasticity of 1.28 , pure monopsonistic wage setting would result in workers receiving just 56.2 per cent of their marginal revenue product. Nonetheless, Figure 2 and Table 8 make clear that this does not affect our findings regarding the procyclicality of the firm-level labour supply elasticity. Notably, the effect of an increase in the unemployment rate on the elasticity remains almost the same. Due to the low elasticity estimates, however, wages are expected to move much stronger over the cycle. Consider again a rise in the unemployment rate by 2.5 percentage points. Using the estimates from Table 8 the elasticity is expected to drop to 0.94 . Thus, under pure monopsonistic wage setting workers would just get 48.0 per cent of their marginal productivity, and wages are expected to drop by 14.5 per cent.

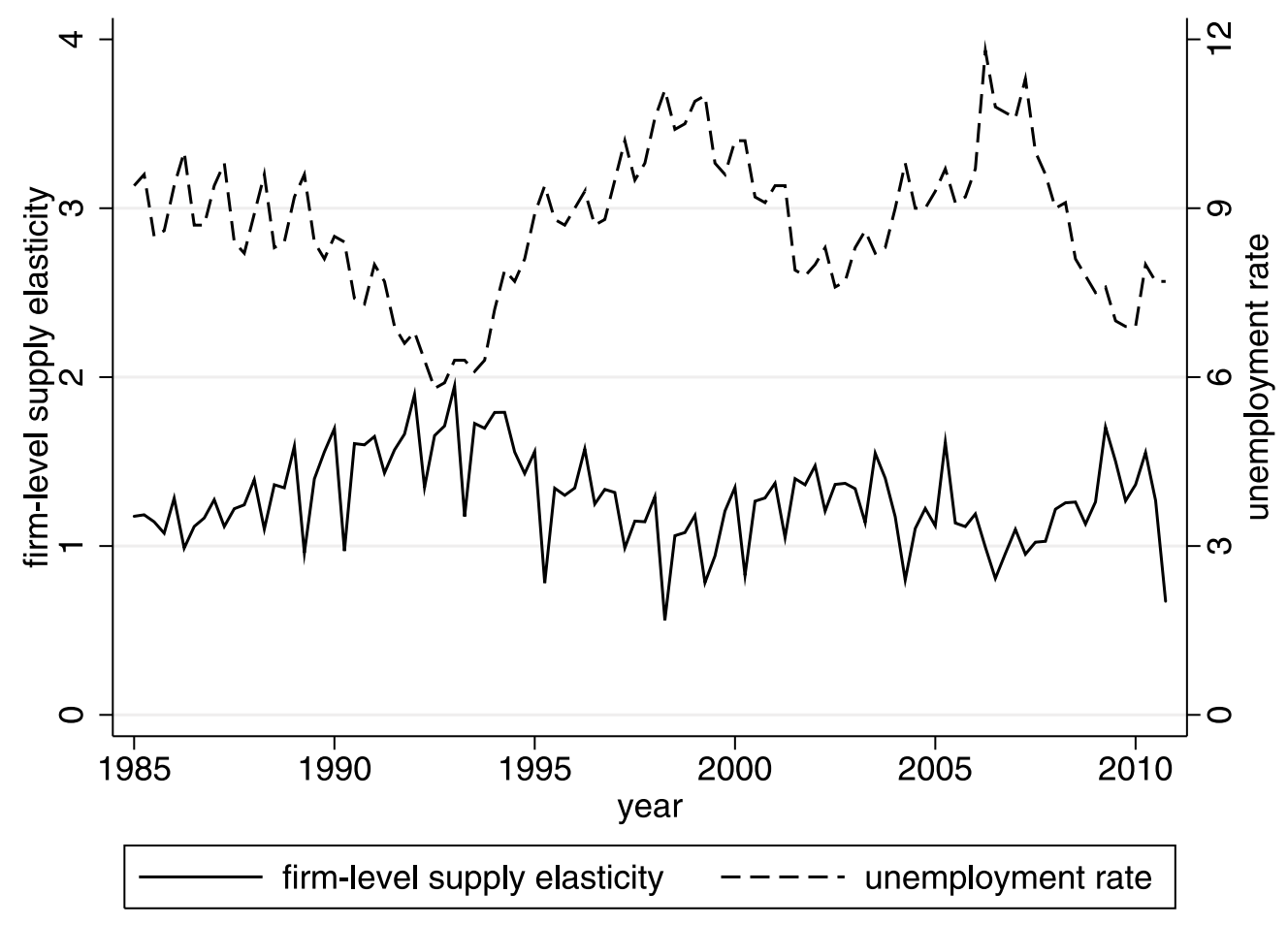

Figure 2: Lagged aggregate unemployment rate and estimated firm-level labour supply elasticity when controlling for unobserved time-invariant worker heterogeneity 
Table 8: Firm-level labour supply elasticity and lagged unemployment rate when controlling for unobserved time-invariant worker heterogeneity

\begin{tabular}{lccc}
\hline & Model 1 & Model 2 & Model 3 \\
\hline Unemployment rate & $-0.141^{* *}(0.013)$ & $-0.143^{* *}(0.012)$ & $-0.143^{* *}(0.013)$ \\
2nd quarter (dummy) & & $-0.194^{* *}(0.073)$ & $-0.195^{* *}(0.075)$ \\
3rd quarter (dummy) & & $-0.165^{* *}(0.036)$ & $-0.164^{* *}(0.032)$ \\
4th quarter (dummy) & & $-0.184^{* *}(0.037)$ & $-0.184^{* *}(0.031)$ \\
Year & & & $0.022^{* *}(0.007)$ \\
Year ${ }^{2} / 100$ & & & $-0.097^{* *}(0.029)$ \\
Constant & $1.282^{* *}(0.018)$ & $1.418^{* *}(0.038)$ & $1.354^{* *}(0.049)$ \\
\hline
\end{tabular}

Notes: The data sets used are a 5 per cent random sample of the IEB and a quarterly version of the BHP, 1985-2010. The regression sample is described in Table 6. The regressand is the firm-level labour supply elasticity. Newey-West standard errors (with lag length four) in parentheses. $* * / *$ denotes statistical significance at the $1 / 5$ per cent level. The lagged aggregate unemployment rate is centred around its mean.

While these numbers seem unreasonably high, we conclude from this check of robustness that our findings from Sections 4.1 and 4.2 do not suffer from omitted variables bias due to unobserved worker heterogeneity correlated with workers' wages. Given that our previous results do not suffer from downward bias stemming from controlling for job tenure, we regard them as our preferred specification.

\subsection{Cyclicality and the prevailing level of unemployment}

Up to now, we have found robust evidence that both the firm-level labour supply elasticity and workers' entry wages move procyclically. What is more, we also saw that under monopsonistic wage setting cyclical changes in the elasticity would generate a procyclicality in wages that is of similar magnitude to the one observed in workers' entry wages. So far, we have restricted the impact of the aggregate unemployment rate on both the elasticity and entry wages to be independent of the current state of the labour market, i.e. independent of the prevailing level of unemployment. It is tempting, though, to conjecture that deteriorating labour market prospects are felt more by workers when the labour market is tight than in a situation with already poor outside opportunities. In other words, the impact of the aggregate unemployment rate on the firm-level labour supply elasticity may be more pronounced for low levels of unemployment. 
To check whether our insights are robust to this change in specification, we now redo our analysis adding the squared unemployment rate and its interaction with the log wage as covariates to the exponential and logit models used to arrive at estimates of the separation rate and recruitment elasticities. We thus allow the impact of the aggregate unemployment rate on the respective elasticity to depend on the prevailing state of the labour market. As is clear from Table 9, which presents the main results obtained from fitting the modified exponential and logit models, the coefficients of the interaction of log wage and the squared unemployment rate are statistically significant in all three regressions. So the unemployment rate indeed has a different impact on the separation rate and recruitment elasticities depending on the prevailing level of unemployment. Nevertheless, our estimates of the firm-level labour supply elasticity (and its components) summarised in Table 10 are quantitatively very similar to those from our previous analysis shown in Table 3 in Section 4.1. Furthermore, a plot of the elasticity

Table 9: Separation rate and recruitment elasticities when allowing for interactions with quadratic unemployment

Exponential model for separation rate to employment

log wage

log wage $\times$ lagged unemployment rate

log wage $\times$ lagged unemployment rate $^{2}$

$-0.015^{* *}(0.001)$

Exponential model for separation rate to non-employment

log wage

$-2.737^{* *}(0.081)$

log wage $\times$ lagged unemployment rate

$0.272^{* *}(0.019)$

log wage $\times$ lagged unemployment rate $^{2}$

$-0.016^{* *}(0.001)$

Logit model for hiring probability from employment

$\begin{array}{lr}\text { log wage } & 1.633^{* *}(0.139) \\ \text { log wage } \times \text { lagged unemployment rate } & -0.136^{* *}(0.032) \\ \text { log wage } \times \text { lagged unemployment rate } & 0.010^{* *}(0.002)\end{array}$

Notes: The data sets used are a 5 per cent random sample of the IEB and a quarterly version of the BHP, 1985-2010. Standard errors clustered at person level in parentheses. **/* denotes statistical significance at the $1 / 5$ per cent level. Apart from the squared unemployment rate, covariates included are the same as in Table 2. Detailed results are available on request. 
Table 10: Lagged unemployment rate and the estimated elasticities and weights when allowing for interactions with quadratic unemployment

\begin{tabular}{lrrrr}
\hline & Mean & S.D. & Min & Max \\
\hline Lagged aggregate unemployment rate (per cent) & 8.705 & 1.286 & 5.800 & 11.800 \\
Labour supply elasticity at firm level $\left(\hat{\varepsilon}_{L w}\right)$ & 2.040 & 0.328 & 1.155 & 2.934 \\
Separation rate elasticity to employment $\left(\hat{\varepsilon}_{s w}^{e}\right)$ & -1.422 & 0.062 & -1.636 & -1.372 \\
Separation rate elasticity to non-employment $\left(\hat{\varepsilon}_{s w}^{n}\right)$ & -1.570 & 0.039 & -1.687 & -1.545 \\
Elasticity of the share of hires from employment $\left(\hat{\varepsilon}_{\theta w}^{R}\right)$ & 0.719 & 0.091 & 0.557 & 1.001 \\
Weight of separation elasticity to employment $(\hat{a})$ & 1.370 & 0.164 & 0.692 & 1.841 \\
Weight of separation elasticity to non-employment $(\hat{b})$ & 0.516 & 0.100 & 0.288 & 0.755 \\
Observations (quarters) & \multicolumn{3}{c}{104} \\
\hline
\end{tabular}

Notes: The data sets used are a 5 per cent random sample of the IEB and a quarterly version of the BHP, 1985-2010. The separation rate and recruitment elasticities are estimated using the results from Table 9 The weights are calculated using quarterly sample averages. The firm-level labour supply elasticity is estimated using equation $(10)$.

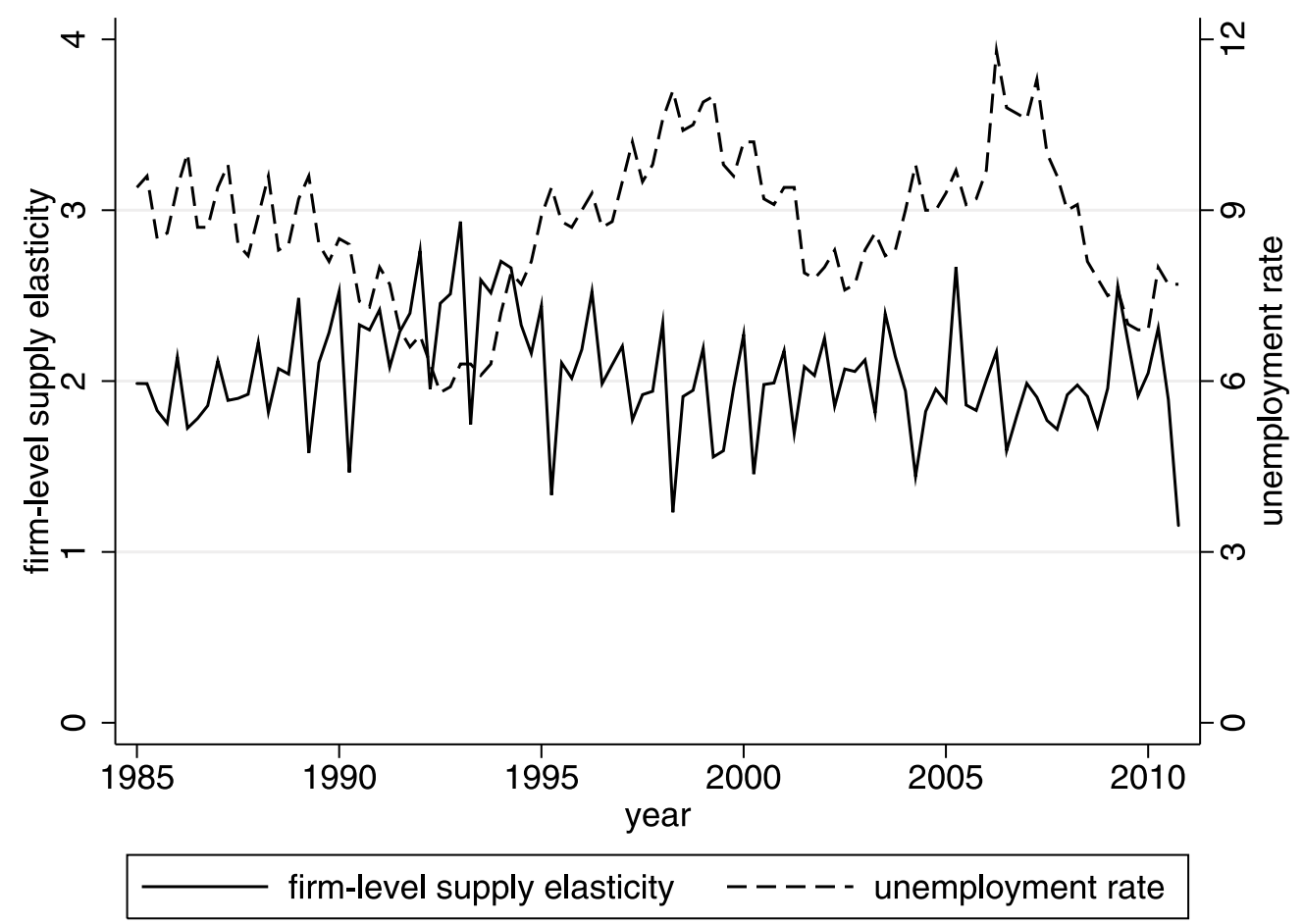

Figure 3: Lagged aggregate unemployment rate and estimated firm-level labour supply elasticity when allowing interactions with quadratic unemployment 
and the unemployment rate time series presented in Figure 3 is again suggestive of a procyclicality of the elasticity.

Regressing the elasticity on the (centred) aggregate unemployment rate, its square, a group of quarter dummies, and a quadratic time trend, we find that at the average level of unemployment in our sample the impact of the unemployment rate on the elasticity is the same as before (see Model 3 in Table 11): An increase in the unemployment rate by one percentage point from 8.7 to 9.7 per cent is associated with a decrease in the elasticity by 0.11 , which is almost identical to the estimate of 0.12 obtained in Section 4.1 , pointing at the robustness of our findings.

Although the coefficient of the squared unemployment rate is not statistically significant at the 10 per cent level in our preferred Model 3, its magnitude is nonetheless nontrivial from an economic point of view, suggesting that a rise in the unemployment rate has a more pronounced impact on the elasticity in tight labour markets with low levels of unemployment: At the minimum unemployment rate in our sample of 5.8 per cent, an increase in the unemployment rate by one percentage point is associated with a decrease in the elasticity by 0.23 . On the other hand, at the maximum unemployment rate of 11.8 per cent, a change in the unemployment rate has no impact on the elasticity at all.

Table 11: Firm-level labour supply elasticity and lagged unemployment rate when allowing for quadratic unemployment effects

\begin{tabular}{|c|c|c|c|}
\hline & Model 1 & Model 2 & Model 3 \\
\hline Unemployment rate & $-0.111^{* *}(0.019)$ & $-0.113^{* *}(0.017)$ & $-0.113^{* *}(0.020)$ \\
\hline Unemployment rate $^{2}$ & $0.018^{*} \quad(0.009)$ & $0.023^{*} \quad(0.010)$ & $(0.013)$ \\
\hline 2nd quarter (dummy) & & $-0.322^{* *}(0.110)$ & $-0.319^{* *}(0.112)$ \\
\hline 3rd quarter (dummy) & & $-0.262^{* *}(0.051)$ & $-0.262^{* *}(0.046)$ \\
\hline 4th quarter (dummy) & & $-0.295^{* *}(0.049)$ & $-0.295^{* *}(0.042)$ \\
\hline Year & & & $0.028^{* *}(0.011)$ \\
\hline 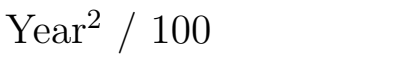 & & & $-0.125^{* *}(0.043)$ \\
\hline Constant & $2.011^{* *}(0.032)$ & $2.224^{* *}(0.054)$ & $2.143^{* *}(0.062)$ \\
\hline
\end{tabular}

Notes: The data sets used are a 5 per cent random sample of the IEB and a quarterly version of the BHP, 1985-2010. The regression sample is described in Table 10, The regressand is the firm-level labour supply elasticity. Newey-West standard errors (with lag length four) in parentheses. $* * / *$ denotes statistical significance at the $1 / 5$ per cent level. The lagged aggregate unemployment rate is centred around its mean. 
While we do not want to over-interpret this finding relying on a statistically insignificant point estimate of the coefficient of the quadratic unemployment rate, it is interesting to note that workers' entry wages are also more responsive to a rise in the unemployment rate when the prevailing level of unemployment is low. Regressing entry wages on the (centred) unemployment rate and its square (see Table 12), an increase in the unemployment rate by one percentage point is associated with a wage drop by $1.2-1.7$ per cent (depending on specification) at the average unemployment rate of 8.7 per cent,

Table 12: Entry wage regressions when allowing for quadratic unemployment rate effects

\begin{tabular}{lrc}
\hline & OLS & Person FE \\
\hline Lagged unemployment rate & $-0.017^{* *}(0.001)$ & $-0.012^{* *}(0.001)$ \\
Lagged unemployment rate ${ }^{2} / 100$ & $0.281^{* *}(0.019)$ & $0.131^{* *}(0.019)$ \\
Immigrant (dummy) & $-0.050^{* *}(0.001)$ & \\
Medium-skilled (dummy) & $0.118^{* *}(0.001)$ & $0.044^{* *}(0.001)$ \\
High-skilled (dummy) & $0.280^{* *}(0.002)$ & $0.272^{* *}(0.002)$ \\
Age 18-25 years (dummy) & $-0.099^{* *}(0.001)$ & $-0.025^{* *}(0.001)$ \\
Age 31-35 years (dummy) & $0.055^{* *}(0.001)$ & $-0.016^{* *}(0.001)$ \\
Age 36-40 years (dummy) & $0.082^{* *}(0.001)$ & $-0.069^{* *}(0.002)$ \\
Age 41-45 years (dummy) & $0.092^{* *}(0.001)$ & $-0.144^{* *}(0.002)$ \\
Age 46-50 years (dummy) & $0.091^{* *}(0.001)$ & $-0.236^{* *}(0.003)$ \\
Age 51-55 years (dummy) & $0.079^{* *}(0.002)$ & $-0.340^{* *}(0.004)$ \\
Plant size 11-50 (dummy) & $0.062^{* *}(0.001)$ & $0.047^{* *}(0.001)$ \\
Plant size 51-200 (dummy) & $0.073^{* *}(0.001)$ & $0.053^{* *}(0.001)$ \\
Plant size 201-1000 (dummy) & $0.124^{* *}(0.001)$ & $0.089^{* *}(0.001)$ \\
Plant size > 1000 (dummy) & $0.166^{* *}(0.001)$ & $0.120^{* *}(0.001)$ \\
Share of low-skilled workers & $-0.085^{* *}(0.001)$ & $-0.060^{* *}(0.001)$ \\
Share of high-skilled workers & $0.373^{* *}(0.003)$ & $0.249^{* *}(0.003)$ \\
Share of female workers & $-0.132^{* *}(0.002)$ & $-0.105^{* *}(0.001)$ \\
Share of immigrant workers & $-0.117^{* *}(0.002)$ & $-0.061^{* *}(0.002)$ \\
Share of part-time workers & $-0.067^{* *}(0.002)$ & $-0.050^{* *}(0.002)$ \\
Median age of workforce / 100 & $0.511^{* *}(0.004)$ & $0.397^{* *}(0.004)$ \\
Observations & & $2,588,212$ \\
\hline
\end{tabular}

Notes: The data sets used are a 5 per cent random sample of the IEB and a quarterly version of the BHP, 1985-2010. The regressand is the log gross daily wage in the first observation of every job spell. Standard errors clustered at the person level in parentheses. ${ }^{* *} / *$ denotes statistical significance at the $1 / 5$ per cent level. Further covariates included are the same as in Table 5 . 
which is almost identical to the estimates from Section 4.2. At the minimum rate of 5.8 per cent, however, the associated fall is 2.0-3.3 per cent whereas the drop accounts to just 0.0-0.4 per cent at the maximum rate of 11.8 per cent. Taken together, these results point at the robustness of our main finding that both firms' monopsony power and workers' wages move procyclically.

\section{Conclusions}

Using administrative linked employer-employee data for West Germany comprising the years 1985-2010, this paper has investigated the cyclical behaviour of the labour supply elasticity to the firm. In line with theoretical expectations, we found that the elasticity moves procyclically. The procyclicality of the elasticity found is pronounced enough to give rise to substantially higher monopsony power during economic downturns when workers are bereft of outside options and labour markets are therefore less competitive.

The long time horizon and high frequency of our data allowed us to substantially improve on Depew and Sørensen's (2013) earlier contribution by using a more sophisticated estimation procedure based on duration models that allows us to address left-truncated and right-censored job durations and to distinguish employment and nonemployment as distinct labour market states. What is more, we are able to use recent data for a whole economy whereas Depew and Sørensen are only able to base their evidence on pre-war data from personnel files of two large U.S. firms, a period including the considerably economic turmoil surrounding the Great Depression and thus unlikely to compare to our period of observation.

In our preferred specification, an economic downturn that causes an increase of the unemployment rate by 2.5 percentage points is expected to decrease the firm-level labour supply elasticity in such a way that workers' wages under pure monopsonistic wage setting would drop by 5.1 per cent on average. This comes close to the observed cyclical pattern of workers' entry wages in our data, where actual wages are expected to decrease by 3.0-3.8 per cent following such an increase in unemployment. While we obviously cannot claim causality here, this finding points at the potential relevance of cyclical fluctuations 
of employers' wage-setting power for the cyclical change in workers' wages. In a check of robustness, we also saw that the expected drop in the elasticity is of very similar magnitude when controlling for unobserved time-invariant worker heterogeneity. So our findings are unlikely to be driven by unobserved worker characteristics related to workers' wages and job mobility. In a further check of robustness, we additionally found some evidence that the procyclicality of the elasticity and workers' entry wages is to a larger extent driven by changes in unemployment in tight labour markets than in labour markets where the prevailing unemployment rate is high and search prospects are poor from the outset.

Following Manning (2003, p. 13) who argues 'that our understanding of labor markets would be much improved by thinking in terms of a model where the labor supply curve facing the firm is not infinitely elastic', we think the procyclicality of workers' wages to be another phenomenon a monopsonistic approach can shed light on. Of course, our findings present only a first indication of the possible relevance of cyclical fluctuations in employers' wage-setting power for the cyclical behaviour of workers' wages. To establish the causal link behind the comovement of workers' wages and the labour supply elasticity at the firm level therefore seems to be a promising avenue for future research. 


\section{References}

AbBring, J.H. and VAN DEN BERG, G.J. (2007), 'The unobserved heterogeneity distribution in duration analysis,' Biometrika, 94(1):87-99.

Ashenfelter, O.C., Farber, H., and Ransom, M.R. (2010), 'Labor market monopsony,' Journal of Labor Economics, 28(2):203-210.

Bartelheimer, P. and Wieck, M. (2005), 'Arbeitslosigkeit und Unterbeschäftigung,' in Soziologisches Forschungsinstitut, Institut für Arbeitsmarkt- und Berufsforschung, Institut für Sozialwissenschaftliche Forschung, and Internationales Institut für empirische Sozialökonomie (eds.), 'Berichterstattung zur sozioökonomischen Entwicklung in Deutschland - Arbeit und Lebensweisen. Erster Bericht,' pp. 271-302, Wiesbaden: VS Verlag für Sozialwissenschaften.

Barth, E. and Dale-Olsen, H. (2009), 'Monopsonistic discrimination, worker turnover, and the gender wage gap,' Labour Economics, 16(5):589-597.

Boal, W.M. and Ransom, M.R. (1997), 'Monopsony in the labor market,' Journal of Economic Literature, 35(1):86-112.

Booth, A.L. and Katic, P. (2011), 'Estimating the wage elasticity of labour supply to a firm: What evidence is there for monopsony?' Economic Record, 87(278):359-368.

BRÜCKER, H. and JAhN, E.J. (2011), 'Migration and wage-setting: Reassessing the labor market effects of migration,' Scandinavian Journal of Economics, 113(2):286-317.

Burdett, K. and Mortensen, D.T. (1998), 'Wage differentials, employer size, and unemployment,' International Economic Review, 39(2):257-273.

Depew, B. and Sørensen, T.A. (2013), 'The elasticity of labor supply to the firm over the business cycle,' Labour Economics, 24(1):196-204.

FALCH, T. (2010), 'The elasticity of labor supply at the establishment level,' Journal of Labor Economics, 28(2):237-266.

(2011), 'Teacher mobility responses to wage changes: Evidence from a quasi-natural experiment,' American Economic Review (Papers and Proceedings), 101(3):460-465.

Fitzenberger, B., Osikominu, A., and Völter, R. (2006), 'Imputation rules to improve the education variable in the IAB employment subsample,' Schmollers Jahrbuch, 126(3):405-436.

Hirsch, B. and JAHN, E.J. (2012), Is there monopsonistic discrimination against immigrants? First evidence from linked employer-employee data, Institute for the Study of Labor, Bonn, IZA Discussion Paper No. 6472.

Hirsch, B., Schank, T., and Schnabel, C. (2010), 'Differences in labor supply to monopsonistic firms and the gender pay gap: An empirical analysis using linked employer-employee data from Germany,' Journal of Labor Economics, 28(2):291-330.

Hotchkiss, J.L. and Quispe-Agnoli, M. (2013), 'The expected impact of state immigration legislation on labor market outcomes,' Journal of Policy Analysis and Management, 32(1):34-59. 
Jacobebinghaus, P. and Seth, S. (2007), 'The German Integrated Employment Biographies Sample IEBS,' Schmollers Jahrbuch, 127(2):335-342.

Manning, A. (2003), Monopsony in Motion: Imperfect Competition in Labor Markets, Princeton, NJ: Princeton University Press.

(2011), 'Imperfect competition in the labor market,' in D.E. Card and O.C. Ashenfelter (eds.), 'Handbook of Labor Economics,' pp. 973-1041, Amsterdam: Elsevier.

Ransom, M.R. and OAxacA, R.L. (2010), 'New market power models and sex differences in pay,' Journal of Labor Economics, 28(2):267-289.

Ransom, M.R. and Sims, D.P. (2010), 'Estimating the firm's labor supply curve in a "new monopsony" framework: Schoolteachers in Missouri,' Journal of Labor Economics, 28(2):331-355.

Ridder, G. and TunAli, İ. (1999), 'Stratified partial likelihood estimation,' Journal of Econometrics, 92(2):193-232.

Spengler, A. (2009), 'The Establishment History Panel,' Schmollers Jahrbuch, 128(3):501-509.

Staiger, D.O., Spetz, J., and Phibbs, C.S. (2010), 'Is there monopsony in the labor market? Evidence from a natural experiment,' Journal of Labor Economics, 28(2):211236.

StüBer, H. (2013), Wage Rigidity in Germany, IAB-Bibliothek No. 340, Bielefeld: W. Bertelsmann Verlag.

WebBer, D.A. (2013a), Firm-level monopsony and the gender pay gap, Institute for the Study of Labor, Bonn, IZA Discussion Paper No. 7343.

(2013b), Firm market power and the earnings distribution, Institute for the Study of Labor, Bonn, IZA Discussion Paper No. 7342. 


\section{Appendix}

Table A.1: Selected descriptives (means)

\begin{tabular}{lr}
\hline Gross daily wage (€) & 85.203 \\
Log gross daily wage & 4.387 \\
Unemployment rate (per cent) & 8.698 \\
Immigrant (dummy) & 0.144 \\
Low-skilled (dummy) & 0.124 \\
Medium-skilled (dummy) & 0.802 \\
High-skilled (dummy) & 0.074 \\
Age (years) & 34.225 \\
Age 18-25 years (dummy) & 0.184 \\
Age 31-35 years (dummy) & 0.203 \\
Age 36-40 years (dummy) & 0.192 \\
Age 41-45 years (dummy) & 0.165 \\
Age 46-50 years (dummy) & 0.129 \\
Age 51-55 years (dummy) & 0.040 \\
Tenure (years) & 3.591 \\
Plant size $\leqslant 10$ (dummy) & 0.155 \\
Plant size 11-50 (dummy) & 0.259 \\
Plant size 51-200 (dummy) & 0.247 \\
Plant size 201-1000 (dummy) & 0.210 \\
Plant size > 1000 (dummy) & 0.129 \\
Share of low-skilled workers & 0.206 \\
Share of medium-skilled workers & 0.618 \\
Share of high-skilled workers & 0.057 \\
Share of female workers & 0.168 \\
Share of foreign workers & 0.097 \\
Share of part-time workers & 0.110 \\
Median age of workforce (years) & 37.609 \\
Observations & 572,616 \\
\hline & \\
\hline
\end{tabular}

Notes: The data sets used are a 5 per cent random sample of the IEB and a quarterly version of the BHP, 1985-2010. 